\title{
Morpho- histological observations on somatic embryogenesis in mature embryo derived callus of Oryza sativa L. cv. Sakha 101
}

\author{
Dina E.Sakr and Reem M.S. Sayed \\ Botany department, Faculty of women for Arts, Science and Education, Ain Shams \\ University.
}

\begin{abstract}
Cellular totipotency is one of the fundamental principles of plant biotechnology. The mature embryo is increasingly recorded as a valuable explant for somatic embryogenesis in rice biotechnology. In present study, rice cells dedifferentiation, proliferation and redifferentiation were investigated by culturing mature rice (Oryza sativa L. cv. Sakha 101) embryos in modified MS media fortified with different growth regulators alone and in combination. Mature embryo tissues competent for tissue culture and the chronological changes of cells morphology and histology were observed. The results showed that callus was induced only from mature rice seed (explant) cultured on MS media supplemented with 2, 4-D ( 2 or $2.5 \mathrm{mg} / \mathrm{l})$ alone while the rest treatments showed negative response. Callus was initiated after 5 days of culture in MS media fortified with the lower 2, 4-D dose as clusters of undifferentiated cell masses while callus initiation was delayed 4 days more by increasing the applied dose. At morphological level, Pale yellowish and friable calli was noted in both tested doses. Calli texture exhibited different appearance, while was slightly nodular in the lower dose it was soft in the higher one. High callus induction frequency (70\%) was estimated for 2mg/l 2, 4-D application while decreased frequency (40\%) was concomitant with dose increment. Histological analysis for somatic embryogenesis revealed that within two weeks of culturing explants on callus induction medium (CIM), somatic embryos development began as clusters of embryonic cells at the peripheral parts of the proliferated calli while nonembryonic cells were observed at the inner regions of the induced callus. Embryogenic cells at the outer cell layer were observed as small and isodiametric with dense cytoplasm and clear nucleus located in the center of the cells, whereas the non embryogenic cells were large, vacuolated and had a very small nucleus located near the cell wall. Embryogenic cells undergo series of ordered divisions and protodermis observed surrounding globular embryo was recorded at the end of culturing in CIM fortified with lower 2, 4-D dose.

On the other hand, culture on MS fortified with higher dose delayed rice cells differentiation and globular stage was recorded two days after subculture embryonic callus into free hormone MS medium. After 2 days of subculture into free hormone MS medium, heart shaped embryo was observed in low dose of 2, 4-D.

This study assists to draw attention to the use of a histological approach as a helpful tool to follow the chronological series of embryo development in vitro.
\end{abstract}

Key wards: differentiation, histology, morphology, Oryza sativa L., somatic embryogenesis and tissue culture. 


\section{Introduction}

Rice (Oryza sativa L.) is an annual grass belonging to tribe Oryzeae under subfamily Oryzoideae in family Poaceae (Jacquemin et al. 2013). It is the world's most important cereal crop with incomparable agricultural and economic importance as being a basic food for more than half of the world's population (Mohanty et al. 2010; Misratia et al. 2015). It represents nearly as $75 \%$ of the caloric intake of 2 billion humans living in Asia, and as much as $33 \%$ of caloric intake of approximately one billion humans in Africa and Latin America (Kinoshita and Mori 2001).

Rice is the second most widely cultivated cereal in the world, after wheat (Pazuki and Sohani 2013). In Egypt, rice plays a significant role as strategic crop for supporting the food self-sufficiency and raising the export (Anis et al. 2016). Frequently, humans eat rice in cooked form to obtain various nutrients, as well as to supplement their caloric intake (Kim et al. 2011). Most of the rice by-products, including rice husk and rice bran, are used as animal feeds. In latest years, rice by-products have received increased interest as functional foods because of their phenolic base compounds, in addition, it have high amounts of vitamins, minerals and fibers, which can help to decrease cholesterol and enact anti-atherogenic activity (Wilson et al. 2002).

In plants, there are two types of embryogenesis: zygotic and somatic embryogenesis. Zygotic embryogenesis is one of the most important steps in the life cycle of plants in which double fertilization occur leading to simultaneous formation of the endosperm and the embryo. Zygotic embryo undergoes cell division and cell differentiation to form a mature plant. Perhaps the main reason for the limited progress in understanding the developmental proceedings in plant embryos is that zygotic embryos of higher plants consist of several tiny cells that grow within motherly tissues (flowers or immature fruits) and it is quite difficult to collect sufficient embryos to study the biological events that occur early in the developmental process (Jimenez 2001). Whereas, Somatic embryogenesis is the process by which somatic cells, under induction conditions, generate embryogenic cells, which go through a series of morphological and biochemical changes (Quiroz-Figueroa et al. 2006), that result in the production of bipolar structure without vascular connection with the original tissue. The development of somatic embryos closely resembles the development of zygotic embryos by both morphologically and physiologically.

Somatic embryogenesis has been proved to be useful and efficient method for mass clonal propagation of selected material, production of mutants and artificial seeds, genetic engineering and germplasm cryopreservation (Gonzalez-Arnao et al. 2008; Hasbullah et al. 2013). In particular, when somatic embryogenesis is integrated with traditional breeding programs and molecular and cell biological techniques, it provides a valuable tool to enhance genetic improvement of crop species (Quiroz-Figueroa et al. 2006). It was found that, one of the most important uses of somatic embryogenesis its employment to study the initial events of zygotic embryogenesis in higher plants where somatic embryo is observable, its various culture conditions can be controlled, and a lack of nutrient is not a restrictive factor for experimentation. The previous characteristics have converted somatic embryogenesis into a model system for studying the morphological, physiological, molecular and biochemical events happening throughout the onset and development of embryogenesis in angiosperms (Quiroz-Figueroa et al. 2006). 
The success of somatic embryogenesis depends on various factors including genotype, explant, plant growth regulator, basal salt, cultural conditions and developmental stages of the mother plants (Panjaitan et al. 2009; Rahman et al. 2015)

Several studies reported that plant growth regulator 2, 4-D was the most suitable auxin for callus induction in rice tissue culture (Chen et al. 1974; Maeda, 1980; Mondal et al. 2013) and however Schulze (2007) indicated that the combination of auxin with other plant growth regulators, such as cytokinins was more effective in regulation of morphogenesis.

Morphological and histological studies of callus and embryo induction of plant are important for enhancing the incidence of callus production and induction of embryogenic callus (Feng et al. 2007; Tan et al. 2009). In addition, the histological and morphological observation of callus can be used for characterizing the somatic embryogenesis process and evaluate the changes in the explant, the cell proliferation in the starting of the induction, and the cellular origin of calluses in embryogenesis (Soares et al. 2014). It is also an object of studies which leading to an understanding of the basis of the totipotency, differentiation, and changes in cell fate (Quiroz-Figueroa et al. 2006).

Therefore, the present study was aimed to evaluate the effect of different growth regulators (auxin and cytokinin), alone or in combination on rice somatic embryogenesis pathway. The functional link between morpho-histological changes during this developmental process was assessed.

\section{2- Materials and Methods}

\subsection{Plant material and explant sterilization}

Healthy and free disease mature rice grains (Oryza sativa L. cv. Sakha 101) were obtained from Field Crops Institute, Agriculture Research Center, Ministry of Agriculture and Land Reclamation, Egypt. Mature rice grains were de-husked manually, washed with tap water to remove dust and other particles, then washed with detergent $(10 \%)$ and rinsed with running tap water for $5 \mathrm{~min}$. Surface sterilization of mature seeds was carried out under laminar air flow cabinet. Seeds were surface sterilized for two minutes in $70 \%$ ethyl alcohol, followed by 50\% Clorox (sodium hypochlorite 5.25\%) supplemented with 1-2 drops of Tween-20 for $30 \mathrm{~min}$, with continuous shaking and finally rinsed five times thoroughly with sterile distilled water according to Ibrahim and El Shihy (2012) with slight modification.

\subsection{Culture media and culture condition}

The medium Murashige and Skoog (1962) full strength composed of macro- and micro- elements, vitamins and glycine fortified with $25 \mathrm{~g} / \mathrm{l}$ sucrose, $0.3 \mathrm{~g} / \mathrm{l}$ casein hydrolysate, $5 \mathrm{~g} / 1$ sorbitol, $0.5 \mathrm{~g} / \mathrm{l} \mathrm{L}$-proline, $0.5 \mathrm{~g} / \mathrm{l} \mathrm{L-glutamine,} 0.45 \mathrm{~g} / \mathrm{l} \mathrm{L}$-alanine and a solidifying agent $8 \mathrm{~g} / \mathrm{l}$ agar (El-Shawaf et al. 2011) was used as a basal media (MS) in this study. To evaluate the effect of different plant hormones alone or in combination, MS medium supplemented with different concentrations of 2,4- dichlorophenoxy acetic acid (2,4-D) (0.5, 2 or $2.5 \mathrm{mg} / \mathrm{l})$, kinetin $(\mathrm{Kn})(0.5,1,1.5,2$ or $2.5 \mathrm{mg} / \mathrm{l})$ was used. The $\mathrm{pH}$ of the medium was adjusted to 5.8 prior to the addition of agar and afterward the media was autoclaved at $121^{\circ} \mathrm{C}, 1.1 \mathrm{~kg} \mathrm{~cm}^{-2}$ for 20 minutes. After autoclaving, media were allowed to cool to approximately $60^{\circ} \mathrm{C}$ then about $30 \mathrm{ml}$ were poured into each sterile Petri dish $(100 \times 15 \mathrm{~mm})$ and sealed with parafilm and 
stored at room temperature for least 3 days before use under completely darkness to examine contamination.

\subsection{Response of mature rice seeds to different hormones}

Ten surface sterilized seeds (explants) were inoculated under the laminar airflow cabinet on free-hormone MS medium and on MS media supplemented with different plant hormones alone or in combination to assess rice cell response. Plant hormone treatments and their concentration were symboled in Table 1 . Within 2 weeks of inoculation, responses of the mature seeds to all treatments were recorded in Table 1 and Figure1.

\subsection{Callus, somatic embryo induction and development through morphological study}

After one week of culture, induced calli were sub cultured for another week on same fresh callus induction media (CIM). All cultures were incubated under controlled condition at $30 \pm 1^{\circ} \mathrm{C}$ at complete darkness. Within 2 weeks of inoculation, callus initiation day, frequency of callus induction as percentage of seeds which produced a callus (Lee et al. 2009), morphological characters of induced calli (type, color \& texture) and days after which somatic embryos initiated was recorded in Table 2 and Figures $2 \& 3$.

For rice somatic embryos development, embryonic calli were sub cultured after 2 weeks from inoculation on free-hormone medium for more one week at $30^{\circ} \mathrm{C}$ in the dark. Rice sample tissues were harvested after 16 days after culture (DAC) for histological analysis.

\subsection{Histological analysis}

Rice tissue samples were harvested at $5^{\text {th }}, 7^{\text {th }}, 9^{\text {th }}, 11^{\text {th }}, 14$, and $16^{\text {th }}$ days after culture (DAC) and were fixed immediately in 10\% formaldehyde, $5 \%$ glacial acetic acid, $50 \%$ of 95\% ethyl alcohol and 35\% d- $\mathrm{H}_{2} \mathrm{O}$ (FAA solution) for $24 \mathrm{~h}$ then preserved in $70 \%$ ethyl alcohol for histological evaluation. The fixed materials were dehydrated through a graded series of ethanol ( $80 \%$ for $48 \mathrm{hrs}, 95 \%$ and $100 \%$ for $2 \mathrm{hrs}$ each). Tissues were then infiltrated in absolute ethyl alcohol: chloroform graded series (3:1, 2:1, 1:1, 1:2, 1:3) for 2 hrs each and finally absolute chloroform for $12 \mathrm{hrs}$ before they were embedded in paraffin wax. Serial sections were prepared at $9 \mu \mathrm{m}$ thickness using a rotatory microtome, mounted on glass slides and double stained with safranin (2\% dissolved in 50\% ethyl alcohol) for 15 minutes and in light green (1\% dissolved in absolute alcohol) for $30 \mathrm{sec}$. It was then rinsed in tap water twice following Johansen (1940) protocol. Samples were examined and photographed with the use of Olympus CX21FS1 microscope (Olympus, Japan) equipped with digital microscope eye piece (HiROCAM type MA 88-500, 5 Mega pixels) (Figures 4-6).

\section{Results and discussion}

\subsection{Response of mature rice seeds to different hormones}

Response of mature seeds was varied according to the type and concentration of growth regulators employed either alone or in combination (Table1). Present results indicated that growth regulator (2, 4-D) alone played an essential role in callus induction. De-husked rice seeds cultured in the free-hormone MS medium was germinated (Figure 1A) and the absence of calli revealed that 2, 4-D is a key factor to stimulate its formation. George et al. (2001) reported that the presence of auxins increased the DNA methylation than usual and 
this might be required for programming of differentiated cells and made them able to begin division.

Similarly, in MS media fortified with kinetin separately, callus was failed to be formed and rice seeds were germinated. Our result was confirmed by Mondal et al. (2013). In $\mathrm{T} 1$ treatment (MS $+0.5 \mathrm{mg} / 1$ 2, 4-D) rice seeds were germinated (tiny root and shoot) instead of callus formation as shown in Figure 1B and this result is on line with Abiramasundari et al. (2014) in which they indicated that the lower level of 2, 4 D concentration (below $1 \mathrm{mg} / \mathrm{l}$ ) was increased the shoot and root growth of the embryo in place of callus induction. While T2 (MS+2mg/l 2, 4-D) and T3 (MS+2.5 mg/l 2, 4-D) treatments tested alone have the ability to induce callus (Figure 1C). In MS media fortified with kinetin in combination with each concentration of 2, 4-D tested, callus was failed to be formed and this result is contrary to the work of Mondal et al. (2013) in which they reported that the use of 2, 4-D along with low concentration of $\mathrm{Kn}(0.5 \mathrm{mg} / \mathrm{l})$ could be helpful for callus production and 2, 4-D 2mg/l alone was the best dose for callus induction. The failure of callus induction using combination of 2,4-D and kn in current study may be due to auxin (2, 4-D)/ cytokinin (Kn) ratio used and it was found that high auxin/ cytokinin ratio is necessary for starting embryogenic callus formation compared to a low ratio for the regeneration of plantlets ( $\mathrm{Ge}$ et al. 2006). As the results obtained previously, the present study was carried out on two concentrations of 2, 4-D ( 2 or $2.5 \mathrm{mg} / \mathrm{l}$ ).

Table (1): Effect of different concentration of 2, 4-D and $\mathrm{Kn}$ alone or in combinations on callus induction derived from rice (Oryza sativa L. cv. Sakha101).within two weeks from inoculation.

\begin{tabular}{|c|c|c|}
\hline $\begin{array}{c}\text { Treatment } \\
\text { number }\end{array}$ & Media tested & Response of explant \\
\hline T0 & free- hormone MS medium & Germination \\
\hline $\mathrm{T} 1$ & $\mathrm{MS}+0.5 \mathrm{mg} / 12,4-\mathrm{D}$ & Germination \\
\hline T2 & $M S+2 \mathrm{mg} / \mathrm{L} 2,4 \mathrm{D}$ & callus \\
\hline T3 & $\mathrm{MS}+2.5 \mathrm{mg} / \mathrm{L} 2,4 \mathrm{D}$ & callus \\
\hline$\overline{\mathrm{T} 4}$ & $\mathrm{MS}+0,5 \mathrm{mg} / \mathrm{L} \mathrm{kn}$ & \multirow{9}{*}{ Germination } \\
\hline T5 & $\mathrm{MS}+1 \mathrm{mg} / \mathrm{L} \mathrm{Kn}$ & \\
\hline T6 & $\mathrm{MS}+1.5 \mathrm{mg} / \mathrm{L} \mathrm{Kn}$ & \\
\hline $\mathrm{T} 7$ & $\mathrm{MS}+2 \mathrm{mg} / \mathrm{L} \mathrm{Kn}$ & \\
\hline T8 & $\mathrm{MS}+2.5 \mathrm{mg} / \mathrm{L} \mathrm{Kn}$ & \\
\hline T9 & $\mathrm{MS}+2 \mathrm{mg} / \mathrm{L} 2,4 \mathrm{D}+2 \mathrm{mg} / \mathrm{L} \mathrm{Kn}$ & \\
\hline T10 & $\mathrm{MS}+2 \mathrm{mg} / \mathrm{L} 2,4 \mathrm{D}+2.5 \mathrm{mg} / \mathrm{L} \mathrm{Kn}$ & \\
\hline $\mathrm{T} 1$ & $\mathrm{MS}+2.5 \mathrm{mg} / \mathrm{L} 2,4 \mathrm{D}+2 \mathrm{mg} / \mathrm{L} \mathrm{Kn}$ & \\
\hline $\mathrm{T} 12$ & $\mathrm{MS}+2.5 \mathrm{mg} / \mathrm{L} 2,4 \mathrm{D}+2.5 \mathrm{mg} / \mathrm{L} \mathrm{Kn}$ & \\
\hline
\end{tabular}

Fig.1 (A-C): Response of plant hormones on mature rice seeds. (A) Germination, (B) Germination with tiny root and shoot in T1 (MS + 0.5mg/1 2, 4-D), (C) Induced callus in T2 (MS + 2mg/l 2, 4-D)

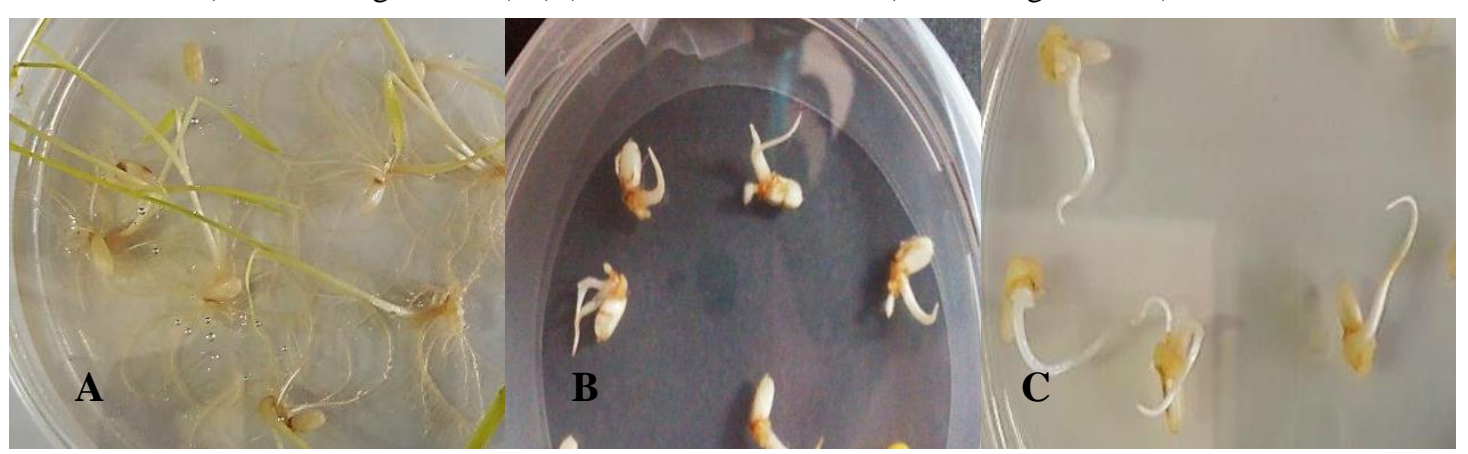




\subsection{Callus, somatic embryo induction and development through morphological study}

The scutellum was appeared to be swollen after 2 days of culture (Figure 2A) then callus was initiated as unorganized cells masses in MS medium supplemented by $2 \mathrm{mg} / 1$ 2, 4D (T2) after 5 days of culture whereas callus initiation was delayed 4 days more after culture in MS medium fortified with 2.5mg/1 2, 4-D (T3). This result confirmed by Benlioğlu et al. (2015) who reported that callus formation was started from mature rice embryos after 4-5 days of culture. In the current study, Friable, pale yellowish and slightly nodular calli were produced after 2 weeks from mature zygotic embryos of rice (Oryza sativa L. cv. Sakha 101) when cultured in T2 (low dose level) treatment while friable, soft and pale yellowish calli was produced when cultured in $\mathrm{T} 3$ treatment as shown in Figure $2 \mathrm{~B}$ and $2 \mathrm{C}$ respectively. Maximum callus induction frequency was recorded in $\mathrm{T} 2$ treatment $(70 \%)$ while the response to callusing reduced (40\%) as the level of 2, 4-D increased in the medium T3 (MS+2.5 mg/l 2, 4-D) as shown in Table 2. The results of the current study are on line with those of Pandey et al. (1994), Abeyaratne et al. (2004), Afrasiab and Jafar, (2011) and Upadhyaya et al. (2015) which reported that concentration of $2 \mathrm{mg} / 1$ 2, 4-D gave the highest response for callus formation in rice while Libin et al. (2012) observed that the frequency of callus decreased when the concentration of 2, 4-D exceeded $2.0 \mathrm{mg} / 1$.

Fig.2 (A-C): Morphological characters of induced calli derived from mature rice seed. (A) Swollen scutellum with non-embryonic callus; (B)Embryonic calli (yellowish, friable and slightly nodular ) derived on T2 treatment (2mg/l 2,4-D); (C) Embryonic calli (yellowish, friable and soft) derived on T3 treatment (2.5mg/1 2,4-D).

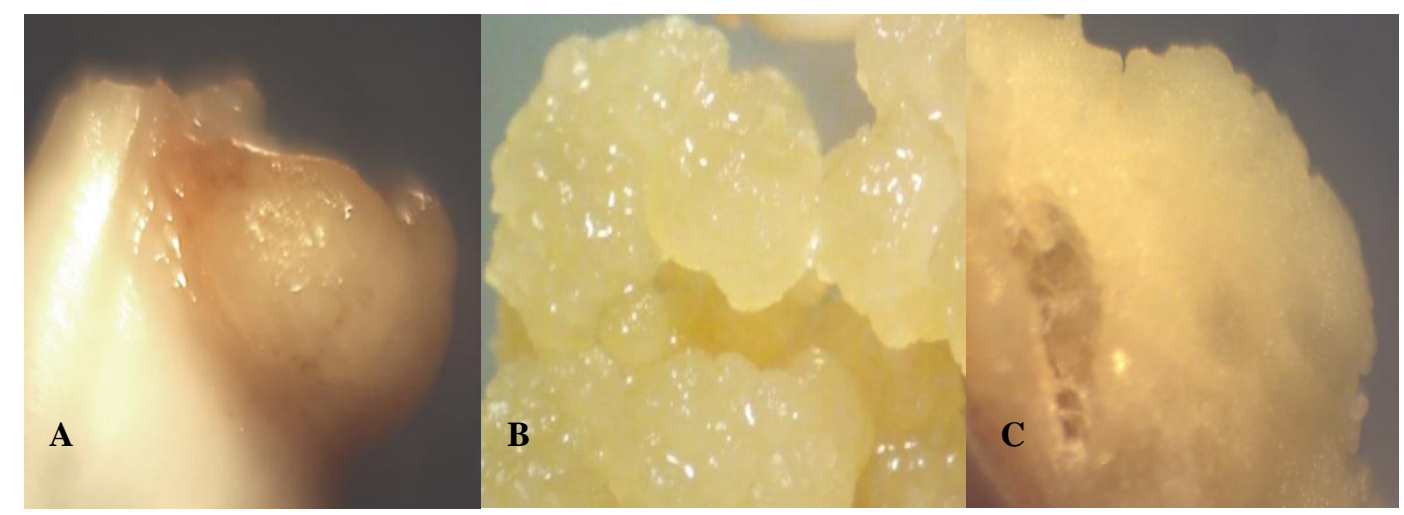

Afterward, globular embryos were observed on the periphery of the proliferated embryogenic calli as initial sign of re-differentiation after 14 days of inoculation on induction and somatic embryo initiation media in T2 treatment (Figure 3A) and after 2 days of culture on free-hormone media, the upper part of the globular embryos enlarged and became bulblike structure and finally assumed the heart shape through further differentiation accompanied with globular embryo (Figure 3A1) while re-differentiation of somatic embryogenesis (globular embryo) was delayed till sixteenth day from inoculation time in high dose level of 2,4-D (Figure 3B). This result is in line of study of Deepti et al. (2002) in which they described the morphological differentiation of globular embryo toward heart shaped embryo. 
Table 2: Effect of different concentration of 2, 4-D on callus induction and initiation somatic embryogenesis derived from mature embryo of rice (Oryza sativa cv. Sakha101).

\begin{tabular}{|c|c|c|c|c|c|c|}
\hline \multirow{2}{*}{$\begin{array}{c}\text { Treatment } \\
\text { number }\end{array}$} & \multirow{2}{*}{$\begin{array}{c}\text { Callus } \\
\text { initiation } \\
\text { days }\end{array}$} & \multicolumn{2}{|c|}{ Callus morphology } & \multirow{2}{*}{$\begin{array}{c}\text { Callus } \\
\text { Induction } \\
\text { frequency } \%\end{array}$} & $\begin{array}{c}\text { Somatic } \\
\text { embryos } \\
\text { initiation days }\end{array}$ \\
\cline { 3 - 6 } & $\mathbf{5}^{\text {th }}$ & $\begin{array}{c}\text { Pale } \\
\text { Yellowish }\end{array}$ & $\begin{array}{c}\text { Slightly } \\
\text { nodular }\end{array}$ & Friable & 70 & $14^{\text {th }}$ \\
\hline $\mathrm{T} 3$ & $\mathbf{9}^{\text {th }}$ & $\begin{array}{c}\text { Pale } \\
\text { yellowish }\end{array}$ & Soft & Friable & 40 & $16^{\text {th }}$ \\
\hline
\end{tabular}

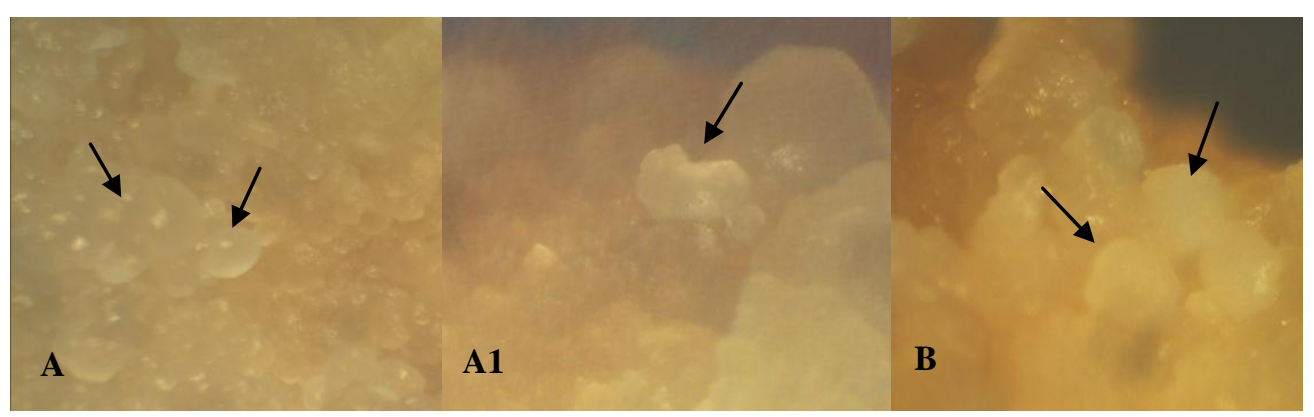

Fig.3 (A, A1 and B): Morphological characters of induced somatic embryos from mature Oryza sativa cv. Sakha 101 seed explant :(A) Globular somatic embryos produced in T2 (2 mg/l 2, 4-D) on somatic embryo induction media at $14^{\text {th }}$ days after culture, (A1) Heart- shaped somatic embryo on development media at $16^{\text {th }}$ days after culture and (B) Embryonic calli show globular somatic embryos cultured on T3 (2.5mg/l 2,4-D) at $16^{\text {th }}$ days after culture.

\subsection{Histological analysis}

In present study, microscopic observation in cross section of scutellum taken before callus initiation revealed that the epithelial cells of scutellum are columnar cells compactly arranged with dense cytoplasm and a prominent nucleus and nucleolus while the ground tissue of scutellum consists of relatively large, compact parenchyma cells (Figure 4A). Callus initiation was detected from the more mitotically active epithelial cells of rice scutellum in both 2, 4-D treatments (T2 and T3) as shown in Figure 4B. Our observation confirmed with previous observations in immature and mature zygotic embryos of Pannicum maximum (Lu \& Vasil 1985) and in rice (Hartke \& Lorz 1989, Vega et al. 2009, Mahmudul Islam et al. 2013). Also callus initiated from meristematic patches proliferated from outermost layer of central mesocotyle bundle in both 2, 4-D treatments (T2 and T3) as shown in Figure 4C and from perivascular parenchyma cells of scutellum in T2. The present result was in agreement with those of Nishimura \& Maeda (1977) and Maeda (1980) whom reported that mesocotyl and scutellum were the precursors of callus formation of rice. 


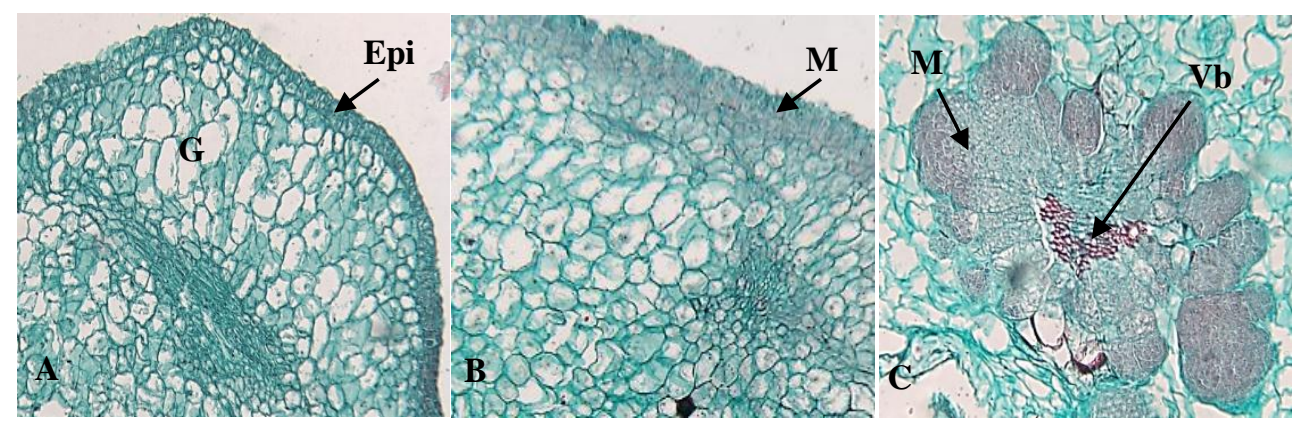

Fig. 4 (A-C): Histological sections showing the position from which derived-callus initiated from mature seed of rice. (A) Internal characters of scutellum (B) Embryonic cells (meristematic cells) induced from the epithelial cells of scutellum; (C) Embryonic cells (meristematic cells) induced from the outermost layer of mesocotyle bundle, where M meristematic cells, Vb vascular bundle, Epi c epithelial cells and $\mathrm{G}$ ground tissue of scutellum.

Histological observation also revealed two types of cells constitute embryogenic calli (Figure 5A); the external cell layers resembled meristematic cells (embryonic cells) consisted of small isodiametric compactly arranged cells in the company of dense cytoplasm and a prominent nucleus and nucleolus (Figure 5B). On the contrary, the internal cell layers (nonembryonic cells), consisted of large cells with abundant intercellular spaces. Most of nonembryonic cells had no nucleus but some had very small nucleus located near the cell wall and large vacuole were observed (Figure 5C). Results of the present study were in agreement with those of Alfonso-Rubi et al. (1999), Vega et al. (2009) and Narciso \& Hattori (2010) which showed the presence of parenchymatic cells in the interior part and meristematic cells in the peripheral part of rice callus.
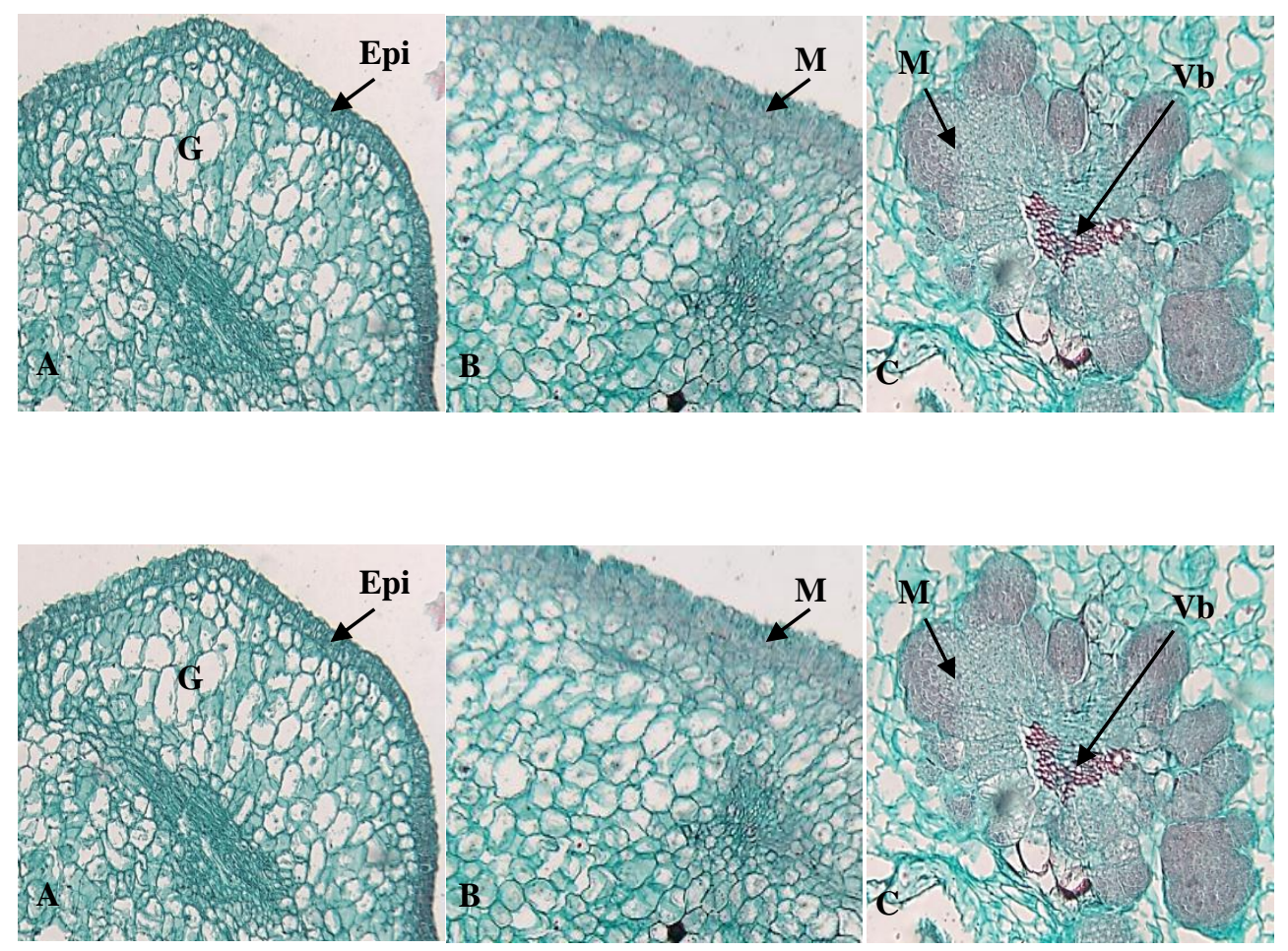

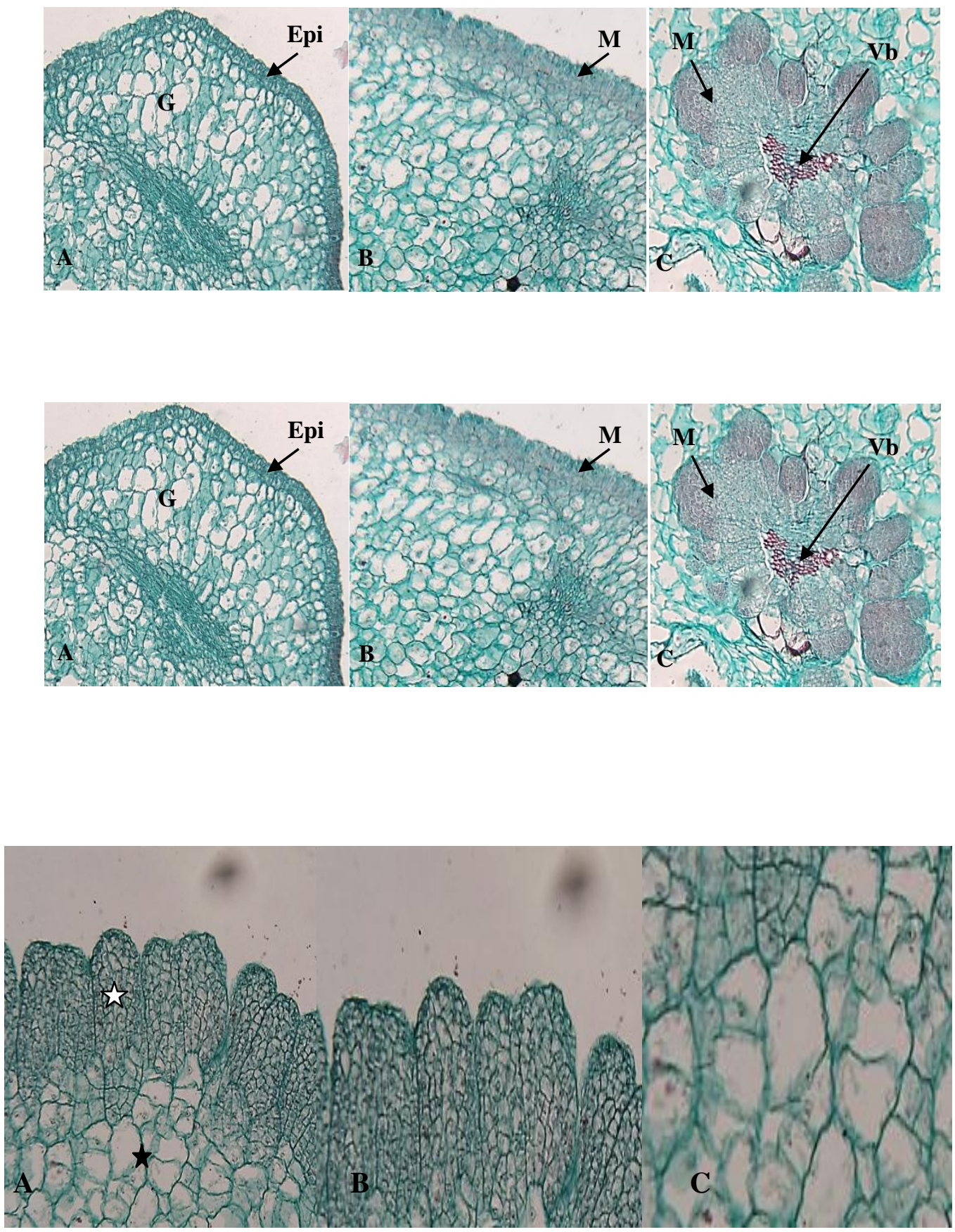

Fig. 5 (A-C): Histological analysis of somatic embryogenesis of Oryza sativa L. cv. Sakha101. (A) embryonic cells ( $_{\boldsymbol{Z}}$ ) and non-embryogenic cells $(\boldsymbol{t})$ (B) Embryonic cells showing isodiametric cells (C) Non-embryogenic cells with large vacuole and small nucleus located near the cell wall.

Histological changes of the tissues during culture period were detected as follows: After five days of culture, callus initiated from the differentiated epithelial cells of scutellum in T2 treatment (MS+ $2 \mathrm{mg} / \mathrm{l} \mathrm{2,4-D)} \mathrm{(Figure} \mathrm{6A)} \mathrm{as} \mathrm{the} \mathrm{first} \mathrm{signs} \mathrm{of} \mathrm{an} \mathrm{active} \mathrm{cellular}$ division and by increasing days of culture (after 7 days of culture) the cellular division was increased and callus proliferation increased (Figure 6B). This result in agreement with Revathi and Arumugam Pillai (2011) who reported that 2, 4-D role in cell division was to 
increase the rate of cell division which leads to increased amount of callus. Also, shoot bud primordium was initiated as a meristematic dome from the outermost layer of mesocotyle bundle and developed to an adventitious shoot apical meristem surrounded by a small leaf primordium by increasing days of culture (Figure 6B1). The current result is in contrast with the result of Nishimura and Maeda, (1977) in which they reported that the outermost layer of the central cylinder in mesocotyl formed stunted primordium of lateral roots by abnormal proliferation of the cells which should have formed lateral roots when 2, 4-D concentration decreased to $3 \times 10^{-5} \mathrm{M}$. Our result may be happened due to the difference in genotype or in the difference of endogenous hormones ratios. Proembryos were observed in the peripheral layer of embryonic calli as early as 9 days after culture in low dose of 2,4-D and were attached to it with a well-known multicellular suspensor (Figure 6C). The present result confirmed by Miroshnichenko et al. (2017) who reported that during the transition form from proembryonic structure to globular embryo, a multicellular suspensor-like structure developed, connecting the globular embryos to the callus. After $11^{\text {th }}$ days of culture (DAC), the number of proembryos was increased. Also, redifferentiation of adventitious shoot was increased (shoot organogenesis). While in T3 treatment (MS+2.5mg/l 2, 4-D) callus initiation was delayed till $9^{\text {th }}$ day of culture (Figure 6D) and adventitious shoot apical meristem surrounded by leaf primordial was observed. Proliferation of embryonic callus was increased by increasing days of culture. After 14 days on the callus and somatic embryo initiation media, globular somatic embryos were observed as a sign of rice cells re-differentiation in T2 treatment. Globular somatic embryos were covered with protodermis and consisted of zones of dividing cells with dense cytoplasm and small vacuoles which distinguished by the absence of vascular connection with the original tissue at basal side (Figure 6E) and this result was confirmed by Miroshnichenko et al. (2017) while in T3 treatment, proembryos were initiated from peripheral layer of embryonic callus and this initiation were delayed as compared with low dose of 2, 4-D (Figure 6F). Finally, After 2 days from subculturing on embryo development media (free-hormone media), globular somatic embryo accompanied with heartshaped somatic embryos were observed in $\mathrm{T} 2$ (2mg/l 2, 4-D). Also root primordia (rhizogenesis) were noticed from preivascular parenchyma cells of scutellum in the same treatment. All somatic embryos covered with protodermis as shown in Figure 6G. Also, adventitious shoot apical meristem and leaf primordia was well developed forming leaf like structure (Figure 6G1). In T3 (2.5 mg/l 2, 4-D) globular somatic embryos were initiated (Figure $6 \mathrm{H}$ ). Globular somatic embryos were covered with protodermis and attached to the embryonic callus with prominent multicellular suspensor like structure (Figure 6H). Also, adventitious shoot apical meristem surrounded by leaf primordia was observed and distinguished by presence of vascular connection with the maternal tissue (Figure 6H1) as shoot organogenesis. The results of the current study are on line with those of Angelo et al. (2009), Demeter et al. ( 2010), Elviana et al. ( 2011) and Steinmacher et al. (2011) who reported that protodermis was a unique character and the first tissue identified somatic embryogenesis development .

In our study, somatic and organogenesis morphogenic pathways was reported to occur simultaneously in T2, T3. The result of the current study is on line with those of Boissot et al. (1990) and Gairi \& Rashid (2004) whom stated that organogenesis and embryogenesis may occur simultaneously, as regeneration pathway. 


\section{Conclusion:}

The current study shed light on the importance of histological approach as a helpful tool to follow the chronological series of embryo development in vitro and indicated that growth regulator (2, 4-D) alone played an essential role in callus induction from matured seeds of Oryza sativa L. cv. Sakha101.

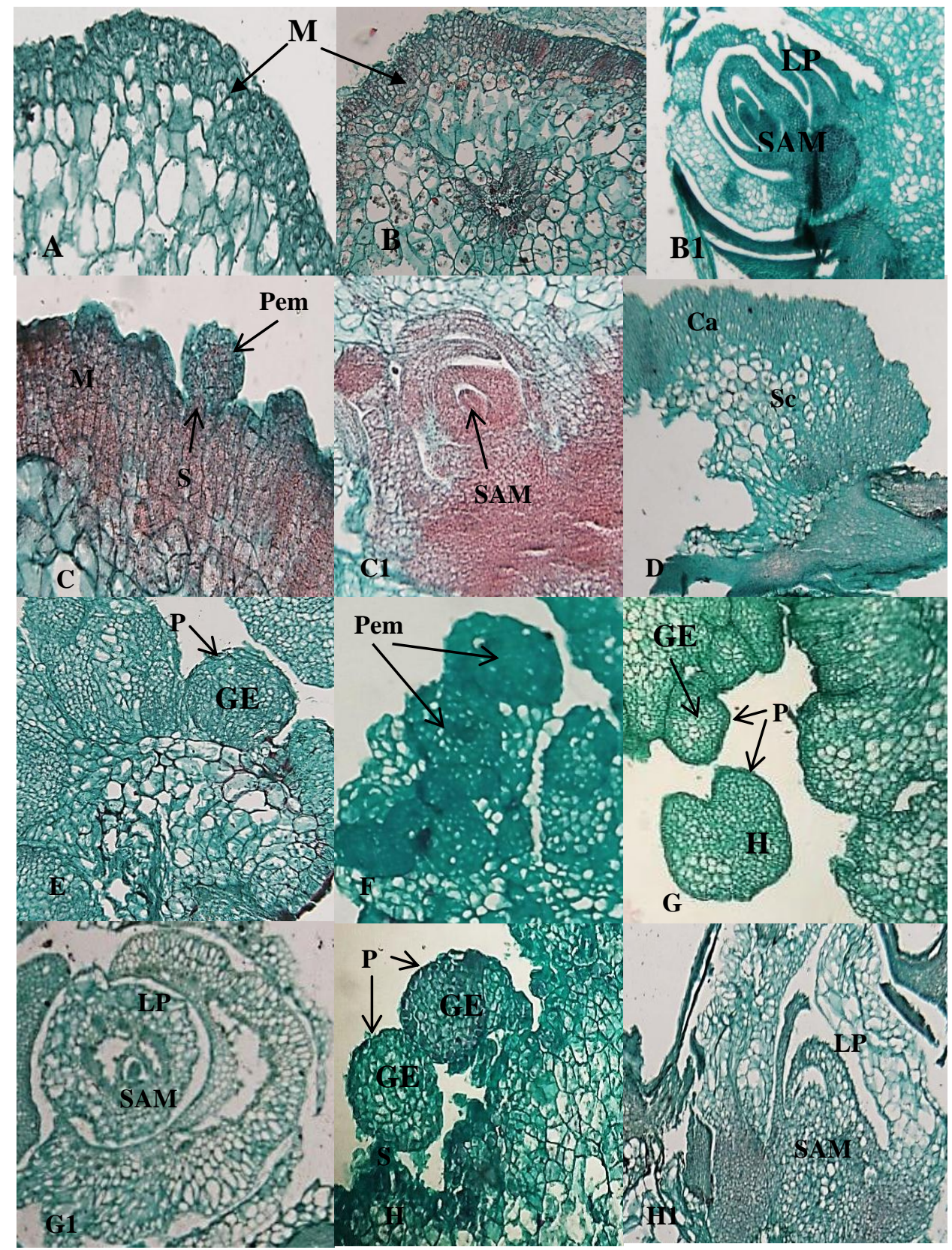

Fig.6 (A-H2): Histological characters of somatic embryogenesis of callus derived from mature rice seeds (A): callus initiation from the epithelial cells of scutellum at $5^{\text {th }}$ DAC in T2 ( $\left.2 \mathrm{mg} / \mathrm{l} 2,4-\mathrm{D}\right)$; (B): increasing in cellular division at $7^{\text {th }}$ DAC in T2; (B1): shoot apical meristem (SAM) with small leaf primordia (LP) in T2; (C, C1): proembryos (pem) and shoot organogenesis (SAM) at $9^{\text {th }}$ day after culture; (D): callus induction (Ca) at $9^{\text {th }}$ day after culture in T3 ( $2.5 \mathrm{mg} / \mathrm{l} 2,4-\mathrm{D})$; (E): globular embryo (GE) at $14^{\text {th }}$ day after culture in $\mathrm{T} 2$; $(\mathrm{F})$ : Proembryo (Pem) at $14^{\text {th }}$ day after culture in T3; (G): globular embryo (GE) accompanied with heart shape somatic embryo (H) in T2; (G1): well differentiated shoot apical meristem (SAM) with leaf primordia (LP) at 
$16^{\text {th }}$ day after culture in T2; $(\mathrm{H})$ : globular embryo and differentiated shoot apical meristem with leaf primordia (H1) at $16^{\text {th }}$ day after culture in T3. Where, Sc scutellum, S suspensor and P protodermis.

\section{References}

Abeyaratne WM, De Silva UN, Kumari HMPS and De Z Abeysiriwardena DS, (2004) Callus induction, plantlet regeneration and occurrence of somaclonal variation in somatic tissues of some indica rice varieties. Annals of the Sri Lanka Department of Agriculture, 6: 111 .

Abiramasundari N, Shanthi P, Kumar D Sassi and Saraswathi R (2014) Callus induction and regeneration in commercial rice cultivars of Tamil Nadu. Int. j. sci. res. agric. sci. 1(2): 2348-3997.

Afrasiab $\mathbf{H}$ and $\mathbf{R}$ Jafar (2011) Effect of different media and solidifying agents on callogenesis and plant regeneration from different explants of rice (Oryza sativa) varietys super Basmati and IRRI-6. Pak.J.Bot. 43(1): 487-501.

Alfonso-Rubi J, Carbonero P and Diaz I (1999) Parameters influencing the regeneration capacity of calluses derived from mature indica and japonica rice seeds after microprojectile bombardment. Euphytica 107: 115-122.

Angelo PCS, Lopes R, Moraes LAC and Cunha RNV (2009) Embryogenic calli induced in interspecific (Elaeis guineenses x E. oleifera) hybrid zygotic embryos. Crop Breeding and Applied Biotechnology 9: 274-277.

Anis G, EL Sabagh A, Ghareb A and EL-Rewainy I (2016) Evaluation of promising lines in rice (Oryza sativa L.) to agronomic and genetic performance under Egyptian conditions. Int. J. Agri. Agri. R. 8(3):52-57.

Benlioğlu B, Tuna DE, Birsin MA and Ozgen AM (2015) Effect of growth regulators on tissue culture parameters in rice (Oryza sativa L.). Ekin J Crop Breed and Gen 1-2:43-46.

Boissot N, Valdez M and Guiderdoni E (1990) Plant regeneration from leaf and seedderived calli and suspension cultures of the African perennial wild rice, Oryza longistaminata. Plant Cell Rep. 9: 447-450.

Chen Y, Liang LT, Zhu J, Wang RF, Li SY, Tian WZ and Zheng SW (1974) Studies on induction conditions and genetic expression of pollen plants in rice, Sci. Sin. 1:40-51.

Deepti S, Shankhdhar SC and Pant RC (2002) Development of Somatic embryos in rice. Ind. J. of Plant Physiol., 7(3): 211-214.

Demeter Z, Surányi G, Molnr AV, Sramkó G, Beyer D, Konya Z, Vasas G, M-Hamvas $\mathbf{M}$ and Máthé $\mathbf{C}$ (2010) Somatic embryogenesis and regeneration from shoot primordia of Crocus heuffelianus. Plant Cell, Tissue and Organ Culture 100 (3): 349-353. 
El-Shawaf I, Hasan AW, Bekhit M, Hasasein ES, Salim T and Bauwe H (2011) Callus induction and plant regeneration of five Egyptian rice genotypes as affected by medium costiturnts. Arab J Biotech 14(2): 279-290.

Elviana M, Rohani ER, Ismanizan I and Normah MN (2011) Morphological and histological changes during the somatic embryogenesis of mangosteen. Biologia Plantarum 55(4): 731-736.

Feng XF, Xie LJ, Chen HB, Li HP and Xu CX (2007) Histological observation on callus and somatic embryo induction in Banana (Musa AAA). J. Fruit Sci., 24(6): 788-791.

Gairi A and Rashid A (2004) TDZ-induced somatic embryogenesis in non-responsive caryopses of rice using a shot treatment with 2, 4-D. Plant Cell Tiss. Org. Cult. 76: 29-33.

Ge XJ, Chu ZH, Lin YJ and Wang SP (2006) A tissue culture system for different germplasms of indica rice. Plant Cell Rep. 25: 392-402.

George EF, Hall MA and De Klerk GJ (2001) Plant Propagation by Tissue Culture 3rd Edition, Vol. 1. Springer, Dordrecht, The Netherlands; 23: 501-507.

Gonzalez-Arnao MT, Panta A, Roca WM, Escobar RH and Engelmann F (2008) Development and large scale application of cryopreservation techniques for shoot and somatic embryo cultures of tropical crops. Plant Cell Tiss Organ Cult. 92:1-13.

Hartke S and H Lörz (1989) Somatic embryogenesis and plant regeneration from various indica rice (Oryza sativa L.) genotypes. J. Genet. Breed. 43: 205-214.

Hasbullah NA, Taha RM, Saleh A and Mohamed N (2013) Physiological responses of callus from Gerbera jamesonii Bolus ex. Hook f. to gamma irradiation. Braz Arch Biol Technol. 55: 411-416.

Ibrahim AS and EI Shihy OM (2012) High- throughput regeneration from mature embryos of eleven commercial rice (Oryza sativa L.) cultivars through somatic embryogenesis using a novel genotype independent protocol. Res.J. Agric. \& Biol. Sci., 8(2): 336-354.

Jacquemin J, Bhatia D, Singh K and Wing R A (2013) The International Oryza Map Alignment Project: development of a genus-wide comparative genomics platform to help solve the 9 billion-people question. Curr. Opin. Plant Biol. 16: 147-156.

Jiménez VM (2001) Regulation of in vitro somatic embryogenesis with emphasis on to the role of endogenous hormones. Rev Bras Fisiol Veg. 13:196-223.

Johansen DA (1940) Plant Micro Techique. New York: McGraw-Hill.

Kim SP, Yang JY, Kang MY, Park JC, Nam SH and Friedman M (2011) Composition of liquid rice hull smoke and anti-inflammatory effects in mice. J Agric Food Chem 59: 45704581 . 
Kinoshitai T and Mori K (2001) In vitro technology for genomic alteration in rice plants. Euphytica, 120: 367-372.

Lee KW, Choi GJ, Kim KY, Ji HC, Park HS, Yoon SH and Lee SH (2009) High frequency plant regeneration from mature seed derived callus of Italian ryegrass (Lolium multiflorum) cultivars, African J Biotech, 8(24): 6828-6833.

Libin A, King PJH, Ong K H, Chubo, JK and Sipen P (2012) Callus induction and plant regeneration of Sarawak rice (Oryza sativa L.) variety Biris. African Journal of Agricultural Research, 7(30): 4260-4265.

Lu C and Vasil IK (1985) Histology of somatic embryogenesis in Panicum maximum (Guinea Grass) Amer. J. Bot., 72: 1908-1913

Maeda E (1980). Organogenesis and cell culture in rice plants under sterile condition (part I). Jpn. Agr. Res. Quart. 14:4-8.

Mahmudul I, Enamul H, Mahbub A, Asadul I, Khalekuzzaman, and Biswanath S (2013) Morphological and Histological Observation of Embryogenic Calli Derived from Immature Embryo of BRRI Dhan28 (Oryza Sativa L.) variety. Research in Plant Biology, 3(5): 21-27.

Miroshnichenko D, Chaban I, C Hernobrovkina M and Dolgov S (2017) Protocole for efficient regulation of in vitro morphogenesis in einkorn (Triticum monococcum L.) a recalcitrant diploid wheat species. PLOS One 12(3): 1-23.

Misratia KM, Islam Robiul M, Ismail MR, Oad FC, Hanafi MM and Puteh A (2015) Interactive effects of gibberellic acid (GA3) and salt stress on growth, biochemical parameters and ion accumulation of two rice (Oryza sativa L.) varieties differing in salt tolerance. J. Food Agric. Env., 13(1): 66-70.

Mohanty S, Narcisco J, Valera HG, Molina I and Matriz JM (2010) Global wheat markets in turmoil: what does this mean for rice? Rice Today, 9(4): 47-48.

Mondal M, Singh RP and Bose B (2013) Standardization of culture medium for somatic embryogenesis of rice var. MTU 7029 international journal of bio-resource and stress management, 4(4): 500-505.

Murashige T and Skoog F (1962) A revised medium for rapid growth bioassays with tobacco tissue culture. Plant Physiol., 15: 473-497.

Narciso JO and Hattori K (2010) Genotypic differences in morphology and ultrastructures of callus derived from selected rice varieties. Philipp Sci Lett 3: 59-65

Nishimura S and Maeda E (1977) Histological studies of callus induction in rice seed. Jpn J Crop Sci 46: 275-285.

Pandey SK, Ramesh, B and Gupta PKS (1994), Callusing and plant regeneration in rice, Indian J. Genet., 54(3): 293-299. 
Panjaitan SB, Abdullah SNA, Aziz MA, Meon S and Omar O (2009) Somatic embryogenesis from scutellar embryo of Oryza sativa L. var. MR219. J Trop Agric Sci. 32: 185-194.

Pazuki A and Sohani M (2013) Phenotypic evaluation of scutellum-derived calluses in 'Indica' rice cultivars. ACTA AGRIC. SLOV 101(2): 239-247.

Quiroz-Figueroa FR, Rojas-Herrera R, Galaz-Avalos RM and Loyola-Vargas VM (2006) Embryo production through somatic embryogenesis can be used to study cell differentiation in plants. Plant Cell Tiss Org Cult 86: 285-301.

Rahman ZA, Ramli A, Hosni H, Kamaruzaman R, Seman ZA, Othman AN, Zainal Z, Uddain J and Subramaniam S (2015) Efficient plant regeneration of Malaysian aromatic rice (Oryza sativa L.) through somatic embryogenesis. Emir. J Food Agric 27: 857-863.

Revathi S and Arumugam Pillai M (2011) In vitro callus induction in rice (Oryza sativa L). Research in Plant Biology, 1(5): 13-15.

Schulze J (2007) Improvements in cereal tissue culture by Thidiazuron: a review. Fruit Veg Cereal Sci Biotechnol 1(2): 64-79.

Soares R, Ferreira, ME, Gamarano MC, Ribeiro RC, Sabino VM and Perreira BMH (2014) The use of histological analysis for the detection of somatic embryos in sugarcane African Journal of Biotechnology. Academic Journals (Kenya), 13(16): 762-767.

Steinmacher DA, Guerra MP, Saare-Surminski K and Lieberei RA (2011) A temporary immersion system improves in vitro regeneration of peach palm through secondary somatic embryogenesis. Annals of Botany 108 (8):1463-1475.

Tan DG, Wang M, Sun XP and Zhang JM (2009) Morphogenesis and histology of calli derived from anthers of Rubber clone reyan7-33-97 (Hevea brasiliensis Mull. Agr.). Chinese J. tropical crops, 30(7): 970-974.

Upadhyaya G, Sen M and Roy A (2015) In vitro callus induction and plant regeneration of rice (Oryza sativa L.) var. Sita, Rupali and Swarna Masuri. Asian J. Plant Sci.Res., 5(5): 2427.

Vega R, Vásquez N, Espinoza AM, Gatica AM and Valdez-Melara M (2009) Histology of somatic embryogenesiss in rice (Oryza sativa cv. 5272). Rev Biol Trop 57:141-150.

Wilson TA, Idreis HM, Taylor CM and Nicolosi RJ (2002) Whole fat rice bran reduces the development of early aortic atherosclerosis in hyper-cholesterolemic hamsters compared with wheat bran. Nutr Res 22: 1319-1332. 


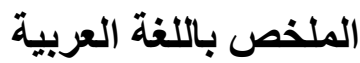

رصد التغيرات الثكل- تثريحية خلال مسار انتاج الاجنة الجسدية المستمدة من الجنين الناضج

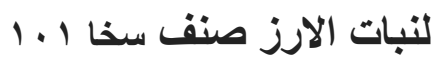

\author{
م. دينا ايهاب صقر- د/ ريم محمد صلاح الدين سيد \\ قسم النبات ، كلية البنات للاداب و العلوم و التربية ، جامعة عين شمس
}

تعتبر القدرة الكامنة للخلية النباتية للتحول الى نبات كامل احد المبادئ الاساسية للتكنولوجيا

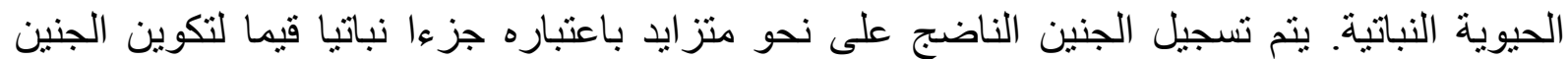

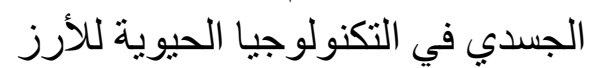

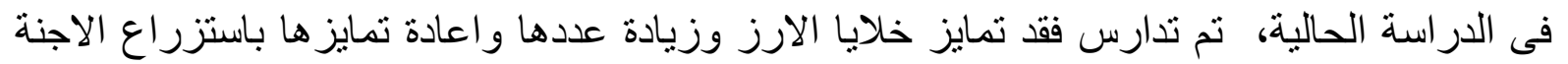

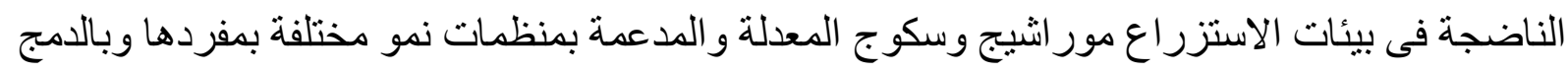

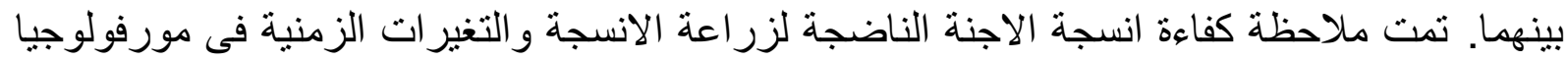

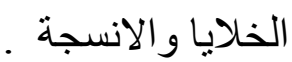

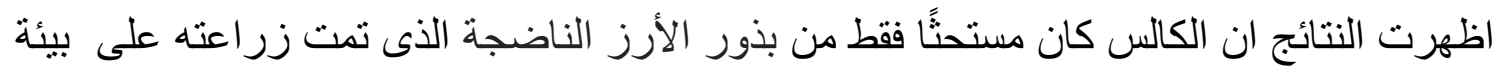

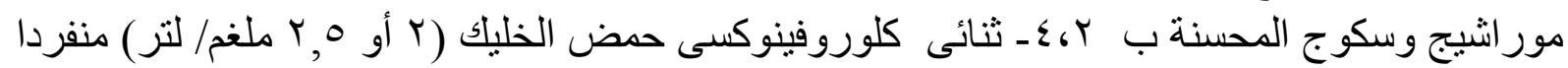

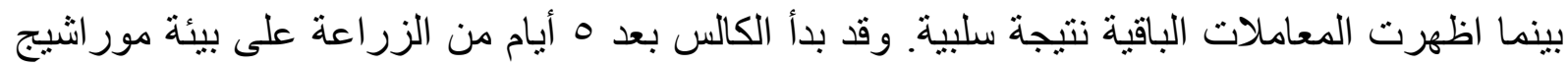

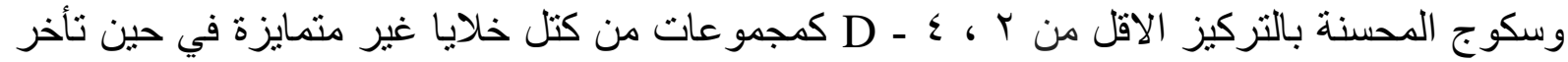

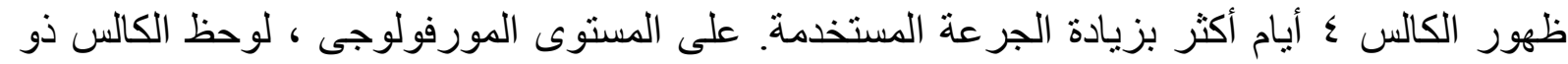

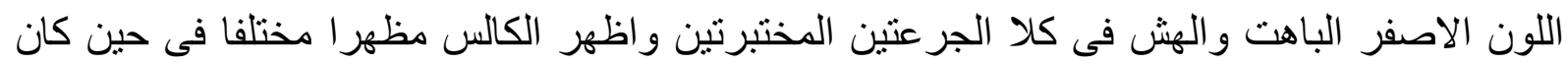

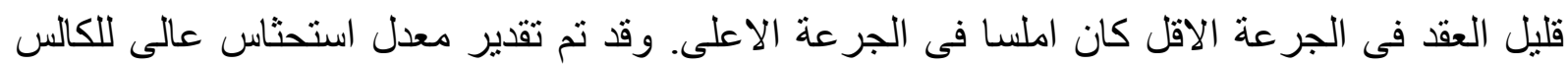

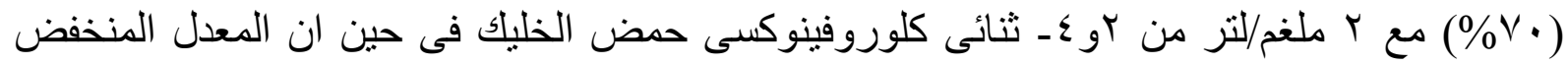

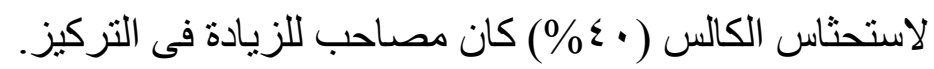

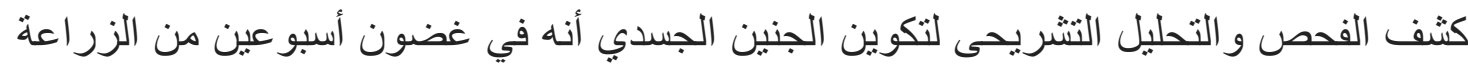

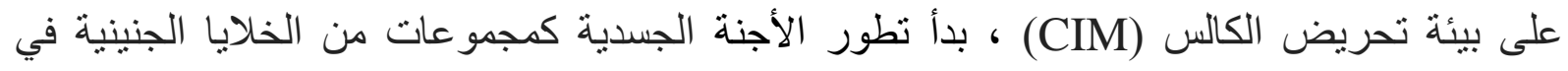

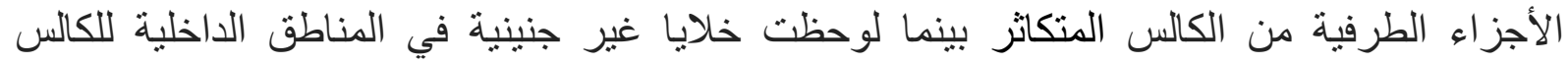

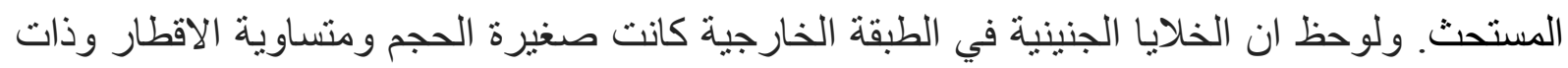

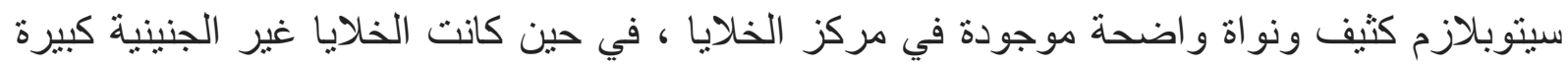

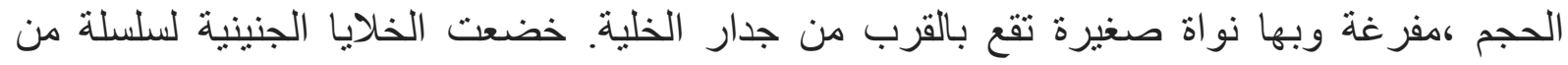

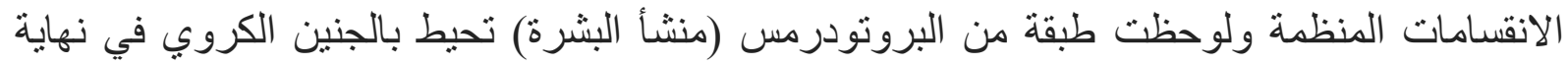

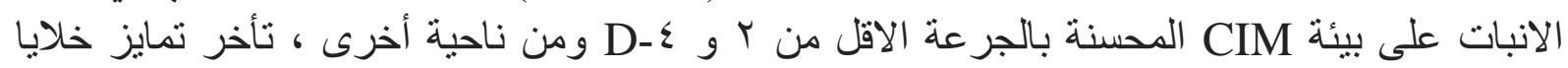

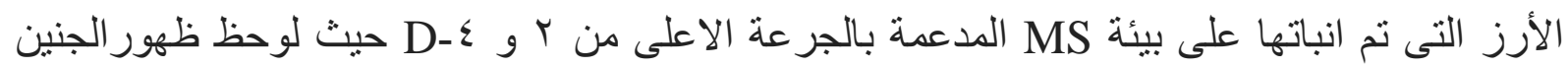

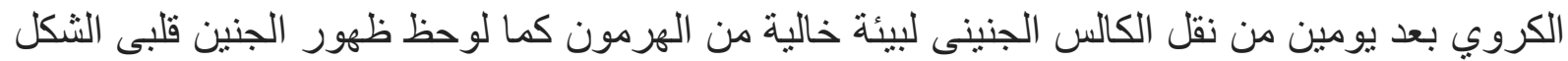

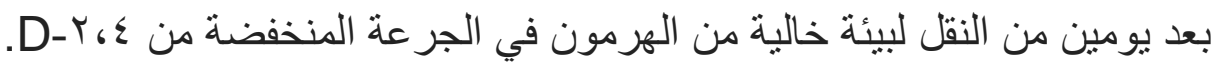

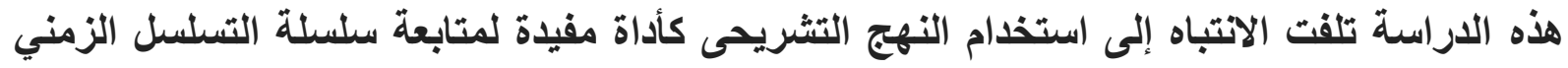

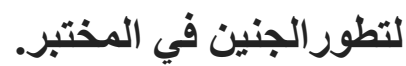

